K. Romić, G. Mitrović*

\title{
IZAZOVI U ZNANSTVENOJ KOMUNIKACIJI - GDJE OBJAVITI ZNANSTVENI RAD
}

UDK 001.817

PRIMLJENO: 4.3.2021.

PRIHVAĆENO: 12.7 .2021

Ovo djelo je dano na korištenje pod Creative Commons Attribution 4.0 International License

SAŽETAK: Kvalitetna znanstvena komunikacija ključna je za učinkovitost znanstvenih istraživanja. Nakon stvaranja znanstvenog rada kroz znanstveno istraživanje, ono se dalje vrednuje $i$ dijeli s drugim znanstvenicima. Na temelju tih znanstvenih radova drugi znanstvenici stvaraju novo znanje kroz nove znanstvene radove. Prisutan je također velik pritisak na znanstvenike u vezi s objavljivanjem radova. $U$ akademskom svijetu postoji određeni pritisak na znanstvenike da što više $i$ što češće objavljuju najnovija istraživanja. Znanstvenici su s jedne strane prisiljeni objavljivati mnogo radova (kvantiteta), dok se s druge strane traži da ti radovi imaju što veći odjek (kvaliteta). lako autori određenog znanstvenog područja poznaju znanstveno publiciranje u svojem području, pojava novih časopisa otežava odabir u kojem časopisu objaviti svoj rad, a pri čemu značajan problem stvaraju tzv. predatorski časopisi. U radu će se dati pregled pokazatelja koji mogu pomoći pri odabiru časopisa te na koji način se mogu prepoznati predatorski časopisi.

Ključne riječi: časopisi, predatorski časopisi, vrednovanje znanstvenog rada, znanstvena komunikacija

\section{UVOD}

Znanstvena komunikacija je neizostavni dio moderne znanosti kao sustav koji proizvodi znanje kroz postupke stvaranja, formalnog i neformalnog dijeljenja, pristupa i korištenja znanstvenih informacija. Osnovni cilj znanstvene komunikacije jest unapređivanje ljudskog znanja, a dijeljenje spoznaja ključno je za postizanje tog cilja (Stojanovski, 2015.). Dijeljenje u znanstvenoj komunikaciji prolazi kroz različite faze te se najčešće provodi kroz završni formalni znanstveni rad koji se dijeli sudionicima u znanstvenoj komunikaciji u tiskanom ili elektroničkom obliku. Današnji ubrzani razvoj znanosti rezultira velikim brojem novih informacija, a i sustav znanstvenoga napredovanja potiče znanstvenike na povećani broj objava. Izraz „publish or perish" (engl. objavi ili nestani) opisuje poziciju znanstvenika u suvre-

*Dr. sc. Kristina Romić, (kromic@nsk.hr), Goranka Mitrović, dipl. ing./dipl. bibl., (gmitrovic@nsk.hr), Nacionalna i sveučilišna knjižnica u Zagrebu, UI. Hrvatske bratske zajednice 4, p.p. 550, 10000 Zagreb. menoj znanstvenoj zajednici. O motivaciji objave znanstvenog rada pisali su mnogi autori (Hardré et al., 2011., Lechuga, Lechuga, 2012., Hardré, 2012.). Motivi mogu biti vanjski (npr. napredovanje u karijeri, povećanje financija) ili unutrašnji (npr. želja za stjecanjem novih znanja). Bez obzira na motivaciju znanstvenika, znanstvenik koji ne objavljuje znanstvene radove kao da i ne postoji. U brojnim znanstvenim disciplinama (poglavito tzv. STEM disciplinama) znanstveni je časopis najvažniji izvor novih informacija. Globalno, broj časopisa neprekidno se povećava. Važno je, stoga, znati odabrati časopis koji će ciljano i kvalitetno prenijeti novu informaciju znanstvenoj zajednici. lako autori određenog znanstvenog područja poznaju znanstveno publiciranje u svojem području, pojava novih časopisa otežava odabir u kojem časopisu objaviti svoj rad. Za znanstvenika, odabir časopisa vrlo je važan korak, jer je objavljivanje u znanstvenim časopisima ujedno i uvjet za napredovanje u nastavnim zvanjima, dobivanje projekata i sl. Hrvatski znanstvenici mogu 
birati časopise u kojima će objaviti svoj rad prema tri kriterija: temeljem indeksiranosti u bibliografskim bazama podataka, temeljem uvjeta za izbor u znanstvena zvanja u Republici Hrvatskoj ili procjenom kvalitete časopisa na temelju njegovih karakteristika prema Pravilniku o uvjetima za izbor u znanstvena zvanja.

\section{PROVJERA KVALITETE ZNANSTVENE PRODUKTIVNOSTI}

Potreba za provjerom kvalitete znanstvenih informacija koje se objavljuju u časopisima postoji od kada su počeli izlaziti prvi časopisi. Razvojem znanosti i pojavom sve većeg broja znanstvenika i porastom broja znanstvenih radova uspostavlja se sustav kontrole kvalitete kroz sustav recenzije. Recenzijskim postupkom procjenjuje se valjanost rukopisa za objavljivanje i osigurava povratna informacija autorima zbog unapređivanja kvalitete rukopisa (Stojanovski, 2018.). Drugi dio kontrole kvalitete obavlja se tek nakon objavljivanja znanstvenog rada, na temelju kvantitativnih pokazatelja korištenja, čitanosti i citiranosti. Ta se dva načina kontrole kvalitete međusobno nadopunjuju.

\section{Recenzija}

Postupak vrednovanja kvalitete rukopisa znanstvenog rada autora ili skupine autora, koji žele objaviti svoj rad u nekom od formalnih komunikacijskih kanala u znanosti (poput časopisa), a koji provode kolege znanstvenici iz istog ili srodnog područja (engl. peers), jedna je od najvažnijih aktivnosti u znanosti općenito (Vrana, 2011.). Recenzijski postupak formalna je procedura kojom se procjenjuje znanstveni doprinos, inovativnost, značenje za znanstveno područje te interes znanstvene zajednice za temu. Urednici časopisa upravljaju postupkom recenzije te su posrednici između znanstvenika-autora i znanstvenika-recenzenta. Tradicionalni recenzijski postupak najčešće je dvostruko slijepi (autori ne znaju identitet recenzenta, a recenzentima je nepoznat identitet autora) ili jednostruko slijepi (autori ne znaju identitet recenzenta). Svi sudionici znanstvene komunikacije (znanstvenici, izdavači i knjižnice) imaju koristi od recenzije - ona jamči kvalitetu informacije na kojoj se mogu temeljiti nova istraživanja. Tradicionalna recenzija provodi se prije objave rada (engl. pre-publication review), dok se pojavom elektroničkog objavljivanja pojavljuje naknadna recenzija (engl. post-publication review). Postoje različiti modeli recenzija koji se temelje na kombinaciji modela prethodne i naknadne recenzije.

\section{Kvantitativni pristup vrednovanju znanstvenog rada}

Do 60-ih godina 20. stoljeća vrednovanje objavljenih znanstvenih radova provodilo se isključivo recenzijskim postupkom koji je i danas neizostavan dio svake prosudbe znanstvenog postignuća. Pojava novih informacijskih tehnologija, rast broja znanstvenih informacija te potreba za objektivnijim vrednovanjem, donijeli su i postupak kvantitativnog vrednovanja znanstvenika temeljem njihovih publikacija, odnosno temeljem obilježja bibliografskih i citatnih baza podataka u kojima su one zastupljene (Petrak, 2001.).

Kvantitativnom, bibliometrijskom analizom i njezinim parametrima moguće je otkriti relevantne aspekte znanstvenog rada. Rezultatima bibliometrijskih analiza također je moguće učinkovito pratiti i vrednovati položaj znanstvenih i visokoškolskih institucija, a bibliometrijska ocjena uspješnosti može se upotrijebiti i kod izrade izvješća za međunarodnu i domaću evaluaciju istih (van Raan i van Leeuwen, 2002.). Bibliometrijska istraživanja temelje se na citatnim bazama podataka.

Citatne baze, uz bibliografske informacije o zastupljenim radovima, sadrže i podatke o referencijama navedenim uz svaki zastupljeni rad, tj. podatke o citranosti. Pojava Science Citation Indexa (SCI); (Garfield, 2007.) 60-tih godina prošloga stoljeća predstavlja početak bibliometrije kao značajnog područja u istraživanjima znanosti (Zauder, 2014.). Danas, glavni citatni indeksi okupljeni su na platformi Web of Science (WoS) kompanije Clarivate Analytics ${ }^{1}$ (WoS, 2021.), u kolekciji citatnih baza podataka Web of Science Core Collection (WoSCC). Journal Citation Reports (JCR) je pomagalo za kvantitativno rangiranje, vrednovanje, kategoriziranje i komparaciju časopisa koji sadrži statističke podatke o ukupnom broju citata koje su dobili radovi objavljeni

'https://clarivate.libguides.com/webofscienceplatform 
u nekom časopisu, broju članaka koji su objavIjeni u tom časopisu (Jokić, 2005.) kao i čitav niz drugih bibliometrijskih parametara o časopisima, a koje izračunava na temelju dva glavna citatna indeksa Science Citation Index Expanded (SCI-E) i Social Sciences Citation Indeks (SSCI). Za Arts \& Humanities Citation Indeks (A\&HCl) ne izračunavaju se bibliometrijski pokazatelji o časopisima kao niti za novu citatnu bazu iz kolekcije WoSCC Emerging Sources Citation Index (ESCI). Od 2016. JCR se nalazi na platformi InCites unutar platforme WoS i predstavlja novu generaciju JCR (JCR, 2021.).

Drugi citatni indeks, Scopus, pojavio se 2004. godine (Boyle, Sherman, 2006.) i od tada gotovo svake godine uvodi nove parametre vrednovanja obrađenih publikacija. Osim znanstvenih časopisa obrađuje knjige, poglavlja u knjigama te zbornike radova svih znanstvenih područja (Life Sciences, Health Sciences, Physical Sciences, Social Sciences \& Humanities). Ne obrađuje prikaze knjiga, niti sažetke sa skupova (Scopus, 2021.). U sklopu Scopusa dostupni su novi metrijski pokazatelji SCImago Journal Rank (SJR) te Source Normalized Impact per Paper (SNIP) dostupan i na stranicama CWTS Journal Indicators (CWTS, 2021.). SJR i SNIP značajni su bibliometrijski parametri kod vrednovanja hrvatskih znanstvenih časopisa. Metrijski pokazatelj o časopisima zastupljenim u Scopusu, SJR, dostupan je i na slobodno dostupnom portalu SCImago Journal and Country Rank (https://www.scimagojr.com/journalrank. php) koji se pojavio u prosincu 2007. godine. $\mathrm{Na}$ temelju statističkih podataka o objavljenim radovima rangira znanstvene i stručne časopise po različitim parametrima (SJR, h-indeks, kvartili, citiranost i dr.); (Butler, 2008.).

Kvantitativno vrednovanje znanstvene djelatnosti znanstvenika hrvatske akademske i znanstvene zajednice definirano je Zakonom o znanstvenoj djelatnosti $i$ visokom obrazovanju te njegovim izmjenama i dopunama tijekom godina te Pravilnikom o uvjetima za izbor u znanstvena zvanja Nacionalnog vijeće za znanost, visoko obrazovanje i tehnološki razvoj (u nastavku teksta: Pravilnik). Uvjeti za izbor u znanstvena zvanja propisani su za svako znanstveno područje (prirodne znanosti, biomedicinu i zdravstvo, tehničke znanosti, biotehničke znanosti, društvene znanosti, humanističke znanosti te interdisciplinarna područja - znanost, umjetnost). Unutar svakog znanstvenog područja definiran je minimalan broj i kategorija radova za izbor u pojedino znanstveno zvanje (znanstveni suradnik, viši znanstveni suradnik, znanstveni savjetnik, znanstveni savjetnik u trajnom zvanju).

Glavni izvor za vrednovanje pristupnika u viša zvanja za većinu znanstvenih područja citatni su indeksi iz kolekcije WoSCC te metrijski pokazatelji o rangu časopisa u kojima pristupnici imaju objavljene radove, promatrano u InCites JCR za časopise zastupljene u SCI-E i SSCI te na platformi SCImago Journal and Country Rank (SJR) za časopise indeksirane u Scopusu. Ovisno o kategoriji unutar JCR ili SJR i mjestu kojem određeni časopis pripada unutar predmetnih kategorija propisan je minimalan broj radova za pojedino znanstveno zvanje. Časopisi u JCR-u i SJR-u razvrstani u predmetne kategorije podijeljeni su u kvartile (Q1-Q4) prema visini faktora odjeka (engl. Impact Factor IF) u JCR-u i bibliometrijskom pokazatelju SJR (Scientific Journal Rankings) prema SCImago Journal and Country Rank. Časopis pripada prvom kvartilu (Q1) ako prema visini svog IF ili SJR pripada među $25 \%$ časopisa s najvišim IF ili SJR unutar skupine časopisa koji su svrstani u određeno predmetno područje (Macan, Petrak, 2015.)

Časopis Sigurnost: časopis za sigurnost u radnoj i životnoj okolini je znanstveno-stručni časopis. Objavljuje znanstvene i stručne radove te izlazi četiri puta godišnje. Područja u koja je časopis Sigurnost kategoriziran na portalu Hrčak su: tehničke znanosti, javno zdravstvo i zdravstvena zaštita, pravo te psihologija (Hrčak, 2020.). Pravilnikom za tehničke znanosti propisane su kategorije radova A, B i C. Radovi kategorije A definirani su na temelju zastupljenosti radova u citatnim indeksima kolekcije WoSCC i rangu časopisa objavljenih radova prema kategorijama (Q) u JCR ili SJR. U području biomedicine i zdravstva propisan je broj znanstvenih radova prema zastupljenosti u časopisima indeksiranim u bazama WoSCC, Scopus ili Medline te rangu časopisa unutar kategorije kojemu pripada (Q1-Q3) prema JCR ili SJR. U području društvenih znanosti radovi pristupnika razvrstani su u skupine A1, A2 i A3. U prvu skupinu radova $\mathrm{A} 1$ ubrajaju se radovi objavIjeni u znanstvenim časopisima zastupljenim u WoSCC ili Scopus prema kategorijama JCR ili SJR (Q1-Q4). Posebno su dodani uvjeti za znanstveno 
polje Ekonomija i Pravo za koje su uključene i druge bibliografske baze podataka.

Časopis Sigurnost zastupljen je u citatnoj bazi podataka Scopus od 2009. godine koja se prema Pravilniku za područje društvenih znanosti ubraja u kategoriju A1. Područje pokrivanja u citatnom indeksu Scopus je Medicine: Public Health, Environmental and Occupational Health te Social Sciences: Safety Research.

\section{ODABIR ČASOPISA ZA OBJAVU ZNANSTVENOG RADA}

Mogući izvori za odabir časopisa za objavljivanje u području tehničkih, prirodnih i društvenih znanosti te biomedicine i zdravstva jest JCR i to za časopise zastupljene u citatnim indeksima SCI-E i SSCI te SciMago Journal and Country Rank za sva znanstvena područja i časopise indeksirane u citatnoj bazi podataka Scopus. U tablicama je za primjer navedeno prvih 20 časopisa prema područjima koja pokriva časopis Sigurnost i to poredanih po padajućim vrijednostima odjeka časopisa (SJR) s portala Scimago Journal \& Country Rank za trenutačno zadnje dostupnu godinu, 2019. Također, za usporedbu, navedeni su i časopisi iz Google Scholar Metrics (GSM); (https://scholar. google.com/intl/en/scholar/metrics.html). Mjerni podaci GSM temelje se na broju citata radova objavljenih u časopisima indeksiranim u Google Scholaru. Autorima omogućuje uvid u utjecaj i vidljivost znanstvenih časopisa prema području i polju kojem časopis pripada (npr. područje: društvene znanosti, polje: medicina zaštite okoliša i medicine rada, područje: zdravstvene i medicinske znanosti, polje: javno zdravstvo i dr.).
Kod odabira časopisa iz GSM potrebno je odabrani časopis još provjeriti i u relevantnim izvorima za vrednovanje znanstvene produktivnosti (citatnim indeksima WoS i Scopus) kako bi bilo sigurno ulazi li časopis u korpus časopisa zastupljenih u citatnim indeksima. $U$ tablicama su prikazani bibliometrijski pokazatelji (IF, SJR, $\mathrm{Q}$, h-indeks) prema kojima se najčešće vrednuju časopisi. Jedan od izvora za odabir časopisa za objavu rada u otvorenom pristupu mogao bi poslužiti i DOAJ (The Directory Of Open Access Journals https://doaj.org/).

U Tablici 1. prikazano je prvih 20 časopisa zastupljenih u citatnoj bazi Scopus. Poredani su po padajućoj vrijednosti SJR parametra unutar područja Medicine: Public Health, Environmental and Occupational Health iz statističke baza časopisa SJR. U navedenom području okupljeno je u 2019. godini 559 časopisa. Časopis Sigurnost nalazi se na 469. poziciji s područjem kvartila Q4. U području Safety Research (Tablica 2) časopis Sigurnost nalazi se na 73. mjestu od 102 časopisa zastupljenih u navedenom području, također ulazi u kategoriju Q4. H-indeks časopisa je 3. Posljednjih godina $\mathrm{H}$-indeks (Hirsch, 2005.) postao je jedan od najčešće korištenih bibliometrijskih pokazatelja u vrednovanju znanstvene produktivnosti. Prednost $\mathrm{H}$-indeksa sastoji se u mogućnosti prikazivanja ravnoteže između broja objavljenih radova i broja citata te primjenjivosti na različit skup elemenata (znanstvenike, časopise, institucije, zemlje). H-indeks časopisa moguće je izračunavati za jednu ili više godina, ovisno o duljini izlaženja nekog časopisa te odjeku radova objavljenih u tom časopisu (Macan, Petrak 2015.). 
Tablica 1. SJR 2019. Područje: Medicine: Public Health, Environmental and Occupational Health

Table 1. SJR 2019. Category: Medicine: Public Health, Environmental and Occupational Health

\begin{tabular}{|c|c|c|c|c|}
\hline Rang & Časopis & SJR & SJR Q & H-index \\
\hline 1 & Clinical Microbiology Reviews & 8,664 & Q1 & 263 \\
\hline 2 & The Lancet Public Health & 6,886 & Q1 & 28 \\
\hline 3 & Annual Review of Public Health & 5,656 & Q1 & 137 \\
\hline 4 & The Lancet Planetary Health & 4,205 & Q1 & 23 \\
\hline 5 & Journal of Occupational Health Psychology & 4,192 & Q1 & 113 \\
\hline 6 & Tobacco Control & 3,318 & Q1 & 117 \\
\hline 7 & Obesity Reviews & 3,141 & Q1 & 151 \\
\hline 8 & Eurosurveillance & 3,014 & Q1 & 95 \\
\hline 9 & Journal of Health Economics & 2,991 & Q1 & 117 \\
\hline 10 & Implementation Science & 2,921 & Q1 & 91 \\
\hline 11 & Environmental Research Letters & 2,675 & Q1 & 109 \\
\hline 12 & Journal of the International AIDS Society & 2,667 & Q1 & 57 \\
\hline 13 & Environmental Health Perspectives & 2,654 & Q1 & 269 \\
\hline 14 & Bulletin of the World Health Organization & 2,502 & Q1 & 158 \\
\hline 15 & Journal of Travel Medicine & 2,499 & Q1 & 55 \\
\hline 16 & American Journal of Preventive Medicine & 2,389 & Q1 & 207 \\
\hline 17 & Perspectives on Sexual and Reproductive Health & 2,36 & Q1 & 92 \\
\hline 18 & American Journal of Public Health & 2,21 & Q1 & 253 \\
\hline 19 & PLoS Neglected Tropical Diseases & 2,148 & Q1 & 121 \\
\hline 20 & Value in Health & 2,132 & Q1 & 97 \\
\hline
\end{tabular}


Tablica 2. SJR 2019. Područje: Social Sciences: Safety Research

Table 2. SJR 2019. Category: Social Sciences: Safety Research

\begin{tabular}{|c|c|c|c|c|}
\hline Rang & Časopis & SJR & SJR Q & H-index \\
\hline 1 & Analytic Methods in Accident Research & 6,091 & Q1 & 30 \\
\hline 2 & Journal of Peace Research & 3,19 & Q1 & 93 \\
\hline 3 & Global Food Security & 2,309 & Q1 & 38 \\
\hline 4 & Journal of Applied Volcanology & 1,642 & Q1 & 19 \\
\hline 5 & Safety Science & 1,24 & Q1 & 100 \\
\hline 6 & Nanolmpact & 1,237 & Q1 & 18 \\
\hline 7 & Crime Science & 1,038 & Q1 & 15 \\
\hline 8 & Journal of Transport and Health & 0,997 & Q1 & 23 \\
\hline 9 & International Journal of Disaster Risk Reduction & 0,964 & Q1 & 34 \\
\hline 10 & IATSS Research & 0,915 & Q1 & 20 \\
\hline 11 & Studies in Conflict and Terrorism & 0,836 & Q1 & 46 \\
\hline 12 & European Journal of International Security & 0,751 & Q1 & 7 \\
\hline 13 & Terrorism and Political Violence & 0,682 & Q1 & 48 \\
\hline 14 & Food Analytical Methods & 0,673 & Q1 & 40 \\
\hline 15 & Traffic Injury Prevention & 0,652 & Q1 & 47 \\
\hline 16 & Therapeutics and Clinical Risk Management & 0,604 & Q1 & 49 \\
\hline 17 & Journal of Occupational Medicine and Toxicology & 0,599 & Q1 & 36 \\
\hline 18 & International Journal of Disaster Risk Science & 0,577 & Q1 & 22 \\
\hline 19 & Surveillance \&amp; Society & 0,539 & Q1 & 43 \\
\hline 20 & Journal of Transportation Safety and Security & 0,533 & Q1 & 16 \\
\hline
\end{tabular}


U tablicama 3 i 4 prikazani su časopisi iz GSM znanstvenih područja: Social Sciences, polje: Environmental \& Occupational Medicine i područje: Health \& Medical Sciences, polje Public
Health prema Googlovoj bazi Google Scholar Metrics za 2019. godinu. Za usporedbu prikazani su biblometrijski parametri navedenih časopisa prema JCR-u i SJR-u.

Tablica 3. Google Scholar Metrics 2019. Polje: Environmental \& Occupational Medicine

Table 3. Google Scholar Metrics 2019. Subcategory: Environmental \& Occupational Medicine

\begin{tabular}{|c|c|c|c|c|c|}
\hline Rang & Časopis & h5-index & h5-median & JCR/Q & SJR/Q \\
\hline 1 & Environmental Health Perspectives & 87 & 115 & Q1 & Q1 \\
\hline 2 & Environmental Research & 79 & 102 & Q1 & Q1 \\
\hline 3 & Journal of Occupational Health Psychology & 51 & 72 & Q1 & Q1 \\
\hline 4 & Epidemiology & 50 & 68 & Q1 & Q1 \\
\hline 5 & $\begin{array}{c}\text { International Journal of Hygiene and Environmental } \\
\text { Health }\end{array}$ & 49 & 72 & Q1 & Q1 \\
\hline 6 & Regulatory Toxicology and Pharmacology & 47 & 76 & Q1 & Q2 \\
\hline 7 & Occupational and Environmental Medicine & 47 & 67 & Q1 & Q1 \\
\hline 8 & Environmental Health & 47 & 63 & Q1 & Q1 \\
\hline 9 & Indoor Air & 42 & 57 & Q1 & Q1 \\
\hline 10 & Current Environmental Health Reports & 40 & 61 & $*$ & Q1 \\
\hline 11 & $\begin{array}{c}\text { Journal of Exposure Science \& Environmental } \\
\text { Epidemiology }\end{array}$ & 35 & 46 & Q1 & Q1 \\
\hline 12 & Critical Reviews in Toxicology & 34 & 47 & Q1 & Q1 \\
\hline 13 & Journal of Occupational and Environmental Medicine & 34 & 47 & Q3 & Q2 \\
\hline 14 & Scandinavian Journal of Work, Environment \& Health & 34 & 47 & Q1 & Q1 \\
\hline 15 & $\begin{array}{c}\text { International Archives of Occupational and } \\
\text { Environmental Health }\end{array}$ & 33 & 48 & Q3 & Q2 \\
\hline 16 & Work & 32 & 42 & Q4 & Q2 \\
\hline 17 & Safety and Health at Work & 31 & 46 & Q2 & Q3 \\
\hline 18 & Toxicology and Industrial Health & 31 & 41 & Q3 & Q2 \\
\hline 19 & Journal of Occupational Rehabilitation & 30 & 48 & Q1 & Q1 \\
\hline 20 & Occupational Medicine & 30 & 45 & Q3 & Q2 \\
\hline
\end{tabular}

*za 2019. u JCR-u nema podataka 
Tablica 4. Google Scholar Metrics 2019. Polje: Public Health

Table 4. Google Scholar Metrics 2019. Subcategory: Public Health

\begin{tabular}{|c|c|c|c|c|c|}
\hline Rang & Časopis & h5-index & h5-median & JCR/Q & $S J R / Q$ \\
\hline 1 & American Journal of Public Health & 87 & 125 & Q1 & Q1 \\
\hline 2 & BMC Public Health & 86 & 117 & Q2 & Q1 \\
\hline 3 & $\begin{array}{l}\text { International Journal of Environmental Research and } \\
\text { Public Health }\end{array}$ & 85 & 117 & Q1 & Q2 \\
\hline 4 & American Journal of Preventive Medicine & 74 & 111 & Q1 & Q1 \\
\hline 5 & $\begin{array}{c}\text { International Journal of Behavioral Nutrition and } \\
\text { Physical Activity }\end{array}$ & 67 & 100 & Q1 & Q1 \\
\hline 6 & Preventive Medicine & 65 & 97 & Q1 & Q1 \\
\hline 7 & Tobacco Control & 62 & 102 & Q1 & Q1 \\
\hline 8 & Nicotine \& Tobacco Research & 59 & 98 & Q1 & Q1 \\
\hline 9 & Bulletin of the World Health Organization & 56 & 81 & Q1 & Q1 \\
\hline 10 & Annual Reviews of Public Health & 55 & 88 & Q1 & Q1 \\
\hline 11 & AIDS and behavior & 53 & 74 & Q1 & Q1 \\
\hline 12 & Health Policy and Planning & 50 & 61 & Q1 & Q1 \\
\hline 13 & European Journal of Public Health & 49 & 74 & Q2 & Q1 \\
\hline 14 & NCHS Data Brief & 43 & 123 & $*$ & Q1 \\
\hline 15 & The Lancet Public Health & 43 & 77 & $*$ & Q1 \\
\hline 16 & International Journal for Equity in Health & 43 & 53 & Q1 & Q1 \\
\hline 17 & Global Health Action & 43 & 51 & Q2 & Q1 \\
\hline 18 & Preventive Medicine Reports & 41 & 51 & * & Q1 \\
\hline 19 & Health Promotion International & 39 & 54 & Q2 & Q1 \\
\hline 20 & International Journal of Public Health & 39 & 49 & Q2 & Q1 \\
\hline
\end{tabular}

*za 2019. u JCR-u nema podataka 


\section{PROCJENA KVALITETE ČASOPISA NA TEMELJU NJEGOVIH KARAKTERISTIKA}

Sve veći dio znanstvenih radova dio je otvorenog pristupa ${ }^{2}$ te su u njima znanstveni radovi besplatno dostupni za čitanje i preuzimanje na mrežnim stranicama časopisa (tvz. zlatni otvoreni pristup) ili u repozitorijima (tzv. zeleni otvoreni pristup); (Gajović, 2018.). lako oba puta otvorenog pristupa omogućuju besplatan pristup krajnjim korisnicima, postoje troškovi objavljivanja koji su visoki i prikupljaju se iz različitih izvora (naplatom od autora, ustanova, društava ili države). Dobit koja se ostvaruje od naplate troškova za objavu rada te raspoloživost digitalnih tehnologija omogućila je pojavu časopisa osnovanih samo zbog ostvarivanja dobiti, a ne širenja znanstvenih ideja. Takvi časopisi nižim naknadama, brzom objavom i lažnim podatcima o indeksiranosti privlače autore te ih nazivamo predatorskim časopisima (Gajović, 2018.). Tri su osnovne karakteristike predatorskih izdavača, i samo se oni izdavači koji imaju sve tri karakteristike mogu smatrati predatorskim izdavačima: objavljuju u otvorenome pristupu, upotrebljavaju model naplate od autora te ne kontroliraju kvalitetu radova koje objavljuju, tj. ne provode recenziju (Hebrang Grgić, Romić, 2018.). Knjižničar Jeffrey Beall prvi je koristio pojam predatorski izdavači s ciljem opisivanja izdavača koji zloupotrebljavaju potrebu znanstvenika za objavom u znanstvenim časopisima (Beall, 2012.). Neki autori smatraju da pojam predatorski izdavači nije prikladan te predlažu druge izraze kao što su: časopisi upitne kvalitete (engl. questionable journals) ili neprovjereni časopisi (engl. bad faith journals); (Dupuis, 2015.), pseudo-časopisi (engl. pseudo-journals); (Laine, Winker, 2017.). Unatoč kritikama, pojam predatorski časopisi široko je prihvaćen. Karakteristike legitimnih, otvoreno dostupnih i predatorskih časopisa prikazane su u Tablici 5.

\footnotetext{
${ }^{2}$ Otvoreni pristup (OA) je globalni pokret čiji je cilj potpora slobodnom protoku znanstvenih informacija i uklanjaju svih prepreka širenja znanstvenoga znanja. Otvoreni pristup odnosi se na model objavljivanja po kojemu je znanstvena literatura u elektroničkome obliku, ponajprije ona objavljena u znanstvenim časopisima, slobodno i neograničeno dostupna mrežnim putem.
}

Tablica 5. Karakteristike legitimnih časopisa i časopisa upitne (neprovjerene) kvalitete

Table 5. Characteristics of legitimate journals and journals of questionable (unverified) quality

\begin{tabular}{|c|c|c|}
\hline $\begin{array}{c}\text { Karakteristike } \\
\text { časopisa }\end{array}$ & Legitimni časopisi & $\begin{array}{l}\text { Predatorski } \\
\text { časopisi }\end{array}$ \\
\hline Cilj i svrha & $\begin{array}{c}\text { Dijeljenje } \\
\text { znanstvenih } \\
\text { informacija }\end{array}$ & Zarada \\
\hline Odabir & $\begin{array}{l}\text { Autori se javljaju } \\
\text { časopisu u kojem } \\
\text { su zainteresirani } \\
\text { objaviti rad }\end{array}$ & $\begin{array}{c}\text { Časopis najčešće } \\
\text { šalje poziv } \\
\text { autorima za } \\
\text { objavu rada } \\
\text { putem neželjene } \\
\text { pošte }\end{array}$ \\
\hline Naslov časopisa & $\begin{array}{c}\text { Odgovara } \\
\text { području koje } \\
\text { pokriva }\end{array}$ & $\begin{array}{c}\text { Često preopćenit } \\
\text { i preopširan } \\
\text { naslov }\end{array}$ \\
\hline $\begin{array}{c}\text { Vrijeme potrebno } \\
\text { za objavu rada }\end{array}$ & $\begin{array}{c}\text { Od nekoliko } \\
\text { tjedana do } \\
\text { nekoliko mjeseci }\end{array}$ & $\begin{array}{c}\text { Brza objava rada: } \\
\text { od nekoliko } \\
\text { dana do nekoliko } \\
\text { tjedana }\end{array}$ \\
\hline Indeksiranje & $\begin{array}{l}\text { U uglednim } \\
\text { bazama }\end{array}$ & $\begin{array}{c}\text { U izmišljenim i/ } \\
\text { ili neselektivnim } \\
\text { bazama }\end{array}$ \\
\hline Recenzija & $\begin{array}{l}\text { Tradicionalna } \\
\text { i/ili otvorena } \\
\text { recenzija }\end{array}$ & $\begin{array}{l}\text { Nema recenzije } \\
\text { ili je izmišljen } \\
\text { podatak o } \\
\text { recenziji }\end{array}$ \\
\hline Kontakt podaci & $\begin{array}{c}\text { Dostupni službeni } \\
\text { kontakt podaci o } \\
\text { časopisu }\end{array}$ & $\begin{array}{l}\text { Često nema } \\
\text { podataka ili su } \\
\text { izmišljeni }\end{array}$ \\
\hline
\end{tabular}

Izvor: Izrađeno prema: Mouton, J.; A. Valentine. The extent of South African authored articles in predatory journals. // South African Journal of Science 113, 7-8(2017), str. 80. DOI: http:// dx.doi.org/10.17159/sajs.2017/20170010

Neke potencijalne opasnosti objave u predatorskim časopisima su:

1. Nevjerodostojnost - čak i visoko kvalitetni radovi ako su objavljeni u takvim časopisima smatraju se manje vjerodostojnima jer takvi časopisi nemaju upravo ono što je bitno za napredak znanosti - razvijeni i kontrolirani sustav provjere kvalitete (Omobowale et al., 2014.)

2. Limitiranost-potencijalni doprinosi radova objavljeni u takvim časopisima su limitira- 
ni, jer časopisi nisu indeksirani u bazama koje kontroliraju kvalitetu časopisa koje uvrštavaju (Clemons et al., 2017.)

3. Dostupnost - rad možda neće biti objavljen ili je samo povremeno dostupan

4. Arhiviranje - rad možda neće biti trajno arhiviran za pretraživanje

5. Autorsko pravo - rad može biti objavljen bez dopuštenja autora

6. Napredovanje - potencijalni nedostatak akademskog priznanja

7. Objava - nemogućnost naknadnog objavljivanja u legitimnom časopisu

8. Podržavanje predatorske industrije

9. Potkopavanje profesionalnog i javnog povjerenja u objavljena istraživanja (Bowman et al., 2018.).

Kako bi znanstvena zajednica mogla lakše razlikovati predatorske od ostalih znanstvenih časopisa, izrađuju se popisi - „crni“ popisi (engl. black lists) popisuju predatorske (loše) časopise, a "bijeli" popisi (engl. white lists) popisuju časopise u otvorenome pristupu čija kvaliteta nije upitna. Najpoznatiji crni popis je Beallov popis predatorskih časopisa i izdavača ${ }^{3}$, a s vremenom su dodana još dva - popis lažnih metričkih pokazatelja $^{4}$ i popis otetih časopisa ${ }^{5}$ (Hebrang Grgić, 2016.). Crni popis je popis Stop Predatory Jornals ${ }^{6}$ koji vrednuje časopise kroz određene kriterije i donosi četiri popisa: popis otetih časopisa, popis predatorskih časopisa, predatorske izdavače i upitne metrijske sustave. Još jedan crni popis časopisa je i Kscien's list koji također vrednuje časopise kroz određene kriterije i donosi pet popisa: izdavači, časopisi, oteti časopisi, upitni metrijski sustavi i predatorske konferencije. ${ }^{7}$ Cabells Scholarly Analytics (komercijalna baza podataka kojoj

${ }^{3}$ Beall's list of predatory publishers, dostupno na: https://archive. fo/085pw

${ }^{4}$ Popis upitnih metrijskih sustava obuhvaća metrijske pokazatelje koji nisu dovoljno transparentni, ne objašnjavaju ili nejasno objašnjavaju način izračuna pokazatelja i ne stavljaju ih u širi kontekst pa zbog toga ne jamče kvalitetu.

${ }^{5}$ Popis otetih časopisa obuhvaća časopise koje su preoteli identitet uglednih časopisa. Oteti časopisi (engl. hijacked journals) su časopisi koji pokušavaju istraživače i znanstvenike prevariti pomoću imena i reputacije originalnih časopisa.

${ }^{6}$ Stop Predatory Jornals, dostupno na: https://predatoryjournals. com/about/, pristupljeno: 18.9.2020.

Kscien's list, dostupno na: https://predatoryjournals.com/about/, pristupljeno: 18.9 .2020 . se pristupa putem pretplate) donosi popise - Predatory Reports - bazu časopisa u kojoj se nalazi preko 14.000 časopisa. U svakom popisu se kategorizirano i detaljno prikazuju istraženi časopisi. ${ }^{8}$

Sve važniju ulogu imaju i „bijeli“ popisi koji popisuju izdavače i/ili časopise u otvorenome pristupu koji imaju dobru uredničku praksu. Jedan od takvih popisa je baza Directory of Open Access Journals (DOAJ) koja ima za cilj sveobuhvatnost i pokrivenost svih otvoreno dostupnih časopisa koji nisu etički sumnjivi (bilo da otvoreni pristup upotrebljavaju za zaradu bez kontrole kvalitete ili ako se sumnja na neki drugi oblik kršenja etičkih načela poput plagiranja). $U$ početku je baza popisivala sve otvoreno dostupne časopise, ali upravo zbog pojave predatorskih časopisa 2015. godine uveli su strože kriterije za uvrštavanje. Stoga danas baza obuhvaća samo one časopise koji su prošli dodatnu provjeru i zadovoljili kriterije za uključivanje. Drugi primjer „bijelog“ popisa jest popis izdavača koji su članovi udruge Open Access Scholarly Publishers Association (OASPA $)^{9}$. Udrugu su osnovali izdavači u otvorenome pristupu koji nisu predatorski kako bi se ogradili od bilo kakvih neetičkih postupaka predatorskih izdavača. Journalytics ${ }^{10}$ je popis koji donosi $\mathrm{Ca}$ bells Scholarly Analytics. Cilj baze jest osigurati objektivan i transparentan alat za pomoć znanstvenicima u odabiru časopisa (Hoffecker, 2018.). Journalytics sadrži više od 11000 časopisa iz 18 znanstvenih disciplina. Časopis se na popis može uključiti samo pozivnicom. Svaki časopis temeljito se istražuje i vrednuje na osnovi određenih kriterija kako bi se osiguralo ispunjenje propisanih standarda (Bisaccio, 2018.). Kao bijeli popis može poslužiti i platforma Web of Science (WoS) s JCR-om kao pomagalom za odabir relevantnih časopisa za pojedina znanstvena područja. Treba

${ }^{8}$ Cabells Scholarly Analyitics. Predatory Reports, dostupno na: https://www2.cabells.com/about-predatory, pristupljeno: 19.9.2020.

${ }^{9}$ Prema kodeksu udruge članovi ne smiju provoditi aktivnosti koje bi nanijele loš ugled objavljivanju u otvorenome pristupu; podatci o izdavaču moraju biti jasno vidljivi na mrežnim stranicama članci moraju proći proces recenzije; svi postupci i pravila u vezi s recenzijom moraju biti jasno objašnjeni na mrežnim stranicama izdavača: časopisi moraju imati urednički odbor sastavljen od uglednih stručnjaka iz područja koje časopis pokriva; sva novčana potraživanja u procesu objavljivanja moraju biti jasno objašnjena i potencijalni autori moraju ih moći lako pronaći; upute autorima moraju biti jasne i vidljive na mrežnoj stranici, a svi nečestiti postupci moraju se prijaviti vijeću udruge.

${ }^{10}$ Cabells Scholarly Analyitics. Journalytics. Dostupno na: https:// www2.cabells.com/about-journalytics, pristupljeno: 18.9.2020. 
spomenuti i novi citatni indeks iz Web of Science Core Collection (WoSCC), Emerging Sources Citation Indeks (ESCI), koji u kriterijima za uključivanje časopisa spominje i poštovanje etičkih normi koje podrazumijevaju da časopis nije predatorski. Takva je baza, iako komercijalna te ne svima dostupna, još jedan „bijeli“ popis koji može pomoći otkrivanju časopisa koji su provjerene kvalitete. SCImago Journal \& Country Rank je platforma koja rangira časopise i zemlje prema bibliometrijskim parametrima citatne baze podataka Scopus, i također može pomoći u odabiru časopisa.

Pri procjeni kvalitete časopisa znanstvenicima mogu pomoći i neki alati:

- Think.Check.Submit (TCS)11 : alat koji je nastao zajedničkim snagama brojnih uglednih baza, udruga i izdavača. Pitanja na koja bi znanstvenici trebali odgovoriti pozitivno kako bi bili sigurni da su odabrali ispravan časopis jesu: poznajete li vi ili vaši kolege časopis? Jeste li čitali članke iz tog časopisa? Je li lako pronaći najnovije objavljene članke? Možete li lako identificirati i kontaktirati izdavača? Je li u časopisu jasno istaknut način provođenja recenzije? Indeksiraju li se članci iz časopisa u bazama kojima se inače koristite? Je li jasno istaknuto što se naplaćuje? Jesu li vam poznati članovi uredničkog odbora? Je li izdavač član uglednih udruga i inicijativa (npr. COPE, DOAJ, OASPA)?

- Quality Open Access Market (QOAM)12: u ovoj bazi časopise vrednuju sami znanstvenici i to tako što ih ocjenjuju pod punim imenom i nazivom institucije. Ocjene su od 1 do 5 te se vrednuje: transparentnost recenzije, upravljanje časopisom, zadovoljstvo cijenom objavljivanja itd. Uz naziv svakog časopisa nalazi se prosječna ocjena, a mogu se pronaći i pojedinačni odgovori ocjenjivača. Prema ocjenama koje su dobili, časopisi imaju četiri boje (zelena označava "jake“ časopise, žuta malo slabije, plava daje izdavaču mogućnost poboljšanja, dok crvena označava časopise koje autori trebaju izbjegavati).

${ }^{11}$ Think. Check. Submit, dostupno na: https://thinkchecksubmit.org/

${ }^{12}$ PQuality Open Access Market, dostupno na: https://www.qoam.eu/
Često je moguće zamijetiti neispravnosti i nedosljednosti kod predatorskih časopisa, a ima i onih koji su pažljiviji i vješto imitiraju legitimne časopise pa je potrebna detaljnija provjera. Zato znanstvenici sami, koristeći vještine informacijske pismenosti, mogu procijeniti kvalitetu časopisa na temelju njegovih karakteristika putem sljedećih pokazatelja: cilj i svrha časopisa su preširoki (npr. u istom časopisu su članci o biomedicini i sociologiji), integritet web stranice (prisutnost pravopisnih i gramatičkih grešaka, neautoriziranih slika, upotreba kolokvijalnog govora), slike su zamućene i nejasne, izdavač je usmjeren na autore, a ne čitatelje (te pridobivanje financijskih sredstava od autora, a na štetu kvalitete časopisa), indeksiranost $\mathrm{u}$ predmetnim bazama podataka i/ili indeksima - (lažne tvrdnje o indeksiranosti u uglednim predmetnim bazama ili prisutnost upitnih metrijskih sustava), nedostatno ili nejasno postupanje $s$ rukopisima, brzo objavljivanje, nejasna politika časopisa oko odustajanja ili povlačenja rada te digitalnog arhiviranja, naknada za objavu rada (tzv. $A P C)$ je vrlo niska, uredništvo koristi elektroničku poštu koja završava na gmail.com, yahoo.com, ili domenom nekog drugog besplatnog pružatelja elektroničke pošte (besplatne adrese nisu jamstvo da kontakt zaista pripada uredništvu) (Shamseer et al., 2017.).

\section{ZAKLJUČAK}

Za znanstvenika, odabir časopisa u kojemu će objaviti svoje znanstvene nalaze vrlo je važan korak, jer je objavljivanje u znanstvenim časopisima, između ostaloga, i uvjet za napredovanje u nastavnim zvanjima, dobivanje projekata i sl. Uz pitanje u kojem časopisu objaviti rad, važno je i pitanje kako procijeniti je li neki znanstveni rad dobar. Kroz recenzijski postupak procjenjuje se valjanost rukopisa za objavljivanje i osigurava povratna informacija autorima zbog unapređivanja kvalitete rukopisa. Drugi dio kontrole kvalitete obavlja se tek nakon objavljivanja znanstvenog rada, na temelju kvantitativnih pokazatelja korištenja, čitanosti i citiranosti. Najprihvatljivije rješenje vrednovanja znanstvenog rada jest kombinacija kvantitativnog i kvalitativnog pristupa. Kvantitativno vrednovanje znanstvene produktivnosti hrvatskih znanstvenika podrazumijeva zastupljenost (indeksiranost) objavljenih znanstve- 
nih radova u multidisciplinarnim i disciplinarnim bibliografskim bazama podataka relevantnima za određeno znanstveno područje propisanim Pravilnikom o uvjetima za izbor u znanstvena zvanja Nacionalnog vijeća za znanost, visoko obrazovanje i tehnološki razvoj te citatne analize temeljene na objavljenim radovima zastupljenim u citatnim bazama podataka. Časopis Sigurnost: časopis za sigurnost u radnoj i životnoj okolini je znanstveno-stručni časopis. Zastupljen je u citatnoj bazi podataka Scopus od 2009., godine koja se prema Pravilniku za područje društvenih znanosti ubraja u kategoriju A1. Područje u koje je časopis Sigurnost razvrstan u citatnom indeksu Scopus je Medicine: Public Health, Environmental and Occupational Health te Social Sciences: Safety Research. Digitalno okružje omogućilo je nove pojavnosti i nova obilježja znanstvenih časopisa. Sve veći broj znanstvenih radova objavljuje se u tzv. otvorenom pristupu te su u njima znanstveni radovi besplatno mrežno dostupni za čitanje i preuzimanje. Dobit koja se ostvaruje od naplate troškova za objavu rada te raspoloživost digitalnih tehnologija omogućila je pojavu časopisa osnovanih samo zbog ostvarivanja dobiti, a ne širenja znanstvenih ideja. Takvi časopisi nižim naknadama, brzom objavom i lažnim podatcima o indeksiranosti privlače autore te ih nazivamo predatorskim časopisima. Kako bi znanstvena zajednica mogla lakše razlikovati predatorske od ostalih znanstvenih časopisa izrađuju se popisi - "crni“ popisi (popisuju predatorske časopise) i "bijeli“" popisi (popisuju časopise u otvorenome pristupu čija kvaliteta nije upitna). Često je moguće zamijetiti neispravnosti i nedosljednosti kod predatorskih časopisa, a ima i onih koji su pažljiviji i vješto imitiraju legitimne časopise pa je potrebna detaljnija provjera. Zato znanstvenici sami koristeći vještine informacijske pismenosti mogu procijeniti kvalitetu časopisa na temelju njegovih karakteristika putem određenih pokazatelja i na temelju ispravne analize odlučiti koje će časopise koristiti za objavu svojih radova.

\section{LITERATURA}

Beall, J.: Beall's list of predatory publishers, dostupno na: https://archive.fo/085pw, pristupljeno: 29.5.2020.
Beall, J.: Predatory publishers are corrupting open access, Nature, 489, 2012., 179-180. Doi:10.1038/489179a

Bisaccio, M.: Cabells' Journal Whitelist and Blacklist: Intelligent data for informed journal evaluations, Learned Publishing, 31, 2018., 3, 243-248. Doi: 10.1002/leap.1164

Bowman M. A., Saultz, J. W., Phillips, W. R.: Beware of Predatory Journals: A Caution from Editors of Three Family Medicine Journals, The Journal of the American Board of Family Medicine, 31, 2018., 5, 671-676 . Doi: 10.3122/ jabfm.2018.05.180197

Boyle F., Sherman D.: Scopus ${ }^{\mathrm{TM}}$ : The Product and Its Development, The Serials Librarian, 49, 2006., 3, 147-153, dostupno na: https:// doi.org/10.1300/J123v49n03_12, pristupljeno 4.2.2021.

Butler, D.: Free journal-ranking tool enters citation market, Nature, 451, 2008., 6, dostupno na: https://www.nature.com/ news/2008/080102/ full/451006a.html. Doi:10.1038/451006a, pristupljeno: 4.2.2021.

Clemons, M., e Silva, M. D. C., Joy, A. A., Cobey, K. D., Mozzarello, S., Stober, C., Hutton, B.: Predatory invitations from journals: more than just a nuisance?, The Oncologist, 22, 2017., 2, 236-240., dostupno na https://theoncologist.onlinelibrary.wiley.com/doi/pdf/10.1634/ theoncologist.2016-0371? src=getftr, pristupljeno: 26.7.2018.

CWTS Journal Indicators, dostupno na: http:// www.journalindicators.com/indicators, pristupljeno: 4.2.2021.

Dupuis, J.: Some perspective on "predatory" open access journals. 1 November 2015., dostupno na: http://confessions.scientopia. org/2015/03/31/some-perspective-on-predatoryopen-access-journals/, pristupljeno: 16.10.2018.

Gajović, S.: Otvoreni pristup i digitalno okružje znanstvenih časopisa. U: Otvorenost u znanosti i visokom obrazovanju. Hebrang Grgić, I. (ur.), Školska knjiga, Zagreb, 2018.

Garfield E.: The evolution of the Science Citation Index, International microbiology, 10, $2007 .$, 
65-69, dostupno na: http://www.im.microbios. org/1001/1001065.pdf, pristupljeno: 4.2.2021.

Google Scholar Metrics. 2021., dostupno na: http:// https://scholar.google.com/intl/en/scholar/ metrics.html, pristupljeno 15.4.2021.

Hardré, P. L., Beesley, A. D., Miller, R. L. \& Pace, T. M.: Faculty Motivation to do Research: Across Disciplines in Research-Extensive Universities, Journal of the Professoriate, 5, 2011., 1.

Hardré, P. L.: Community college faculty motivation for basic research, teaching research, and professional development, Community College Journal of Research and Practice, 36, 2012., 8, 539-561. https://doi. org/10.1080/10668920902973362

Hebrang Grgić, I.: Časopisi i znanstvena komunikacija, Naklada Ljevak, Zagreb, 2016.

Hebrang Grgić, I. \& Romić, K.: „Znanstvene“ informacije u predatorskim časopisima: prijetnja napretku znanosti. U: Zbornik radova, Slobodan pristup informacijama: 18. okrugli stol: Knjižnice i alternativna (druga) istina, Hrvatsko knjižničarsko društvo, Zagreb, 45-58, 2018.

Hirsch, J. E.: An index to quantify and individual's scientific research output, Proceedings of the National Academy of Sciences (PNAS), 102, 2005., 46, 16569-16572; https:// doi.org/10.1073/pnas.0507655102

Hoffecker, L.: Cabells scholarly analytics, Journal of the Medical Library Association (JMLA), 106, 2018., 2, 270-272, Doi: 10.5195/jmla.2018.403

Hrčak, Sigurnost: časopis za sigurnost u radnoj i životnoj okolini, dostupno na: https://hrcak.srce. hr/sigurnost, pristupljeno: 29.5.2020.

JCR: Journal Citation Reports: Learn the Basics, dostupno na: https://clarivate.libguides.com/jcr, pristupljeno: 4.2.2021.

Jokić, M.: Bibliometrijski aspekti vrednovanja znanstvenog rada, Sveučilišna knjižara, Zagreb, 2005.

Laine, C., Winker, M. A.: Identifying predatory or pseudo-journals, Biochemia medica, 27, 2017., 2, 285-291. Doi: https://doi.org/10.11613/ BM.2017.031
Lechuga, V. M., Lechuga, D. C.: Faculty motivation and scholarly work: Self-determination and self-regulation perspectives, Journal of the Professoriate, 6, 2012., 2.

Macan, B., Petrak, J.: Bibliometrijski pokazatelji za procjenu kvalitete znanstvenih časopisa. U: Hrvatski znanstveni časopisi: iskustva, gledišta, mogućnosti, Hebrang Grgić, I. (ur.), Školska knjiga, Zagreb, 2015.

Moller, A.: The case for open access publishing, with special reference to open access journals and their prospects in South Africa, Masters thesis, University of the Western Cape (South Africa), 2006., 44. Dostupno na: http://eprints. rclis.org/7297/1/MollerThesis.pdf, pristupljeno: 25.5.2020.

Mouton, J., Valentine, A.: The extent of South African authored articles in predatory journals, South African Journal of Science, 113, 2017., 7-8. Doi: htp://dx.doi.org/10.17159/ sajs.2017/20170010

Omobowale, A. O., Akanle, O., Adeniran, A. I., Adegboyega, K.: Peripheral scholarship and the context of foreign paid publishing in Nigeria, $\mathrm{Cu}$ rrent Sociology, 62, 2014., 5, 678., dostupno na: http://citeseerx.ist.psu.edu/viewdoc/download?do $\mathrm{i}=10.1 .1 .1031 .7391 \&$ rep=rep1\&type=pdf, pristupljeno: 26.7.2018.

Petrak, J.: Bibliometrijski pokazatelji u ocjenjivanju znanstvenog rada. 1. Objavljivanje i ocjenjivanje rezultata znanstvenog rada, Liječnički vjesnik: glasilo Hrvatskoga liječničkog zbora, 123, 2001., 3-4, 77-81.

Pravilnik o uvjetima za izbor u znanstvena zvanja. Narodne novine, 2017., dostupno na: https://narodne-novine.nn.hr/clanci/ sluzbeni/2017_03_28_652.html, pristupljeno: 29.5.2020.

Scopus: Access and use Support Center. dostupno na: https://service.elsevier.com/app/answers/ detail/a_id/15181/c/10547/supporthub/scopus/, pristupljeno: 29.1.2021.

Shamseer, L., Moher, D., Maduekwe,O., Turner, L., Barbour, V., Burch, R., Clark, J. i sur.: Potential predatory and legitimate biomedical journals: can you tell the difference? A cross-sectional 
comparison, BMC medicine, 15, 2017., 1, No. 28. Doi: https://doi.org/10.1186/s12916-017-0785-9

Stojanovski, J.: (R)evolution of scholarly journals. U: Hrvatski znanstveni časopisi: iskustva, gledišta, mogućnosti, Hebrang Grgić, I. (ur.), Školska knjiga, Zagreb, 2015.

Stojanovski, J.: Otvoreni recenzijski postupak, U: Otvorenost u znanosti i visokom obrazovanju. Hebrang Grgić, I. (ur.), Školska knjiga, Zagreb, 2018.

van Raan, A. F. J., van Leeuwen, Th. N.: Assessment of the scientific basis of interdisciplinary, applied research: Application of bibliometric methods in Nutrition and Food Research, Research Policy, 31, 2002., 4, 611-632, dostupno na: https://www.sciencedirect.com/science/article/pii/ S0048733301001299. (https://
doi.org/10.1016/S0048-7333(01)00129-9), pristupljeno: 29.1.2021.

Vrana, R.: Vrednovanje znanstvenog rada, Vjesnik bibliotekara Hrvatske, 54, 2011., 1/2, 172-192.

Web of Science platform: Introduction. dostupno na: https://clarivate.libguides.com/webofscienceplatform, pristupljeno: 29.1.2021.

Zakon o znanstvenoj djelatnosti i visokom obrazovanju, Narodne novine, br. 123/03. 198/03., 105/04., 174/04., 02/07., 46/07., 45/09., 63/11., 94/13., 139/13., 101/14., 60/15., 131/17.

Zauder, K.: Razvoj scientometrije praćen kroz časopis Scientometrics od početka izlaženja 1978. do 2010. godine, doktorski rad, Filozofski fakultet, Zagreb, 2014.

\title{
CHALLENGES IN SCIENTIFIC COMMUNICATION - WHERE TO PUBLISH A SCIENTIFIC PAPER
}

\begin{abstract}
SUMMARY: Quality scientific communication is key to the effectiveness of scientific research. After creating a scientific paper through scientific research, it is further evaluated and shared with other scientists. Based on these scientific papers, other scientists create new knowledge through new scientific papers. There is also a lot of pressure on scientists to publish papers. In the academic world, there is a certain pressure on scientists to publish the latest research as much and as often as possible. On the one hand, scientists are forced to publish a lot of papers (quantity), while on the other hand, they are required to have as much impact as possible (quality). Although the authors of a certain scientific field are familiar with scientific publishing in their field, the emergence of new journals makes it difficult to choose in which journal to publish their work and where a significant problem is created by the so-called predatory journals. The paper will provide an overview of indicators that can help in the selection of journals and how predatory journals can be identified.
\end{abstract}

Key words: journals, predatory journal, evaluation of scientific work, scientific communication 